\title{
DIE OORNAME VAN DIE HAREM DEUR 'N NUWE KONING.
}

In sy strafrede teen Dawid na die dood van Uria vermeld die profeet Natan onder die weldade, wat die koning van die Here ondervind het, ook die feit, dat Dawid die vroue van Saul as sy vroue ontvang het: ,.... en Ek het die huis van jou heer vir jou gegee, en die vroue van jou heer in jou skoot..." (II Sam. 12:8).

Dit is nogal 'n verrassende meedeling. Nêrens in die geskiedenis van Dawid se troonsbestyging lees ons iets daaromtrent. Tereg merk reeds Keil en Delitzsch by hul bespreking ") van hierdie teks op, dat dit die algemene gewoonte was in die Ooste dat as 'n koning sterf, sy opvolger op die troon ook sy opvolger in die harem was; ons sal daarvan in die loop van hierdie ondersoek 'n paar voorbeelde gee. Keil en Delitzsch gaan dan egter voort met die betoog, dat Dawid wel die bevoegheid gehad het om Saul se vroue te neem, maar dat ons uit hierdie teks nog nie mag opmaak dat hy dit ook werklik gedoen het nie.

Blykbaar het hierdie vrome en geleerde kommentatore, wie se naam altyd met eer genoem sal word, daar beswaar teen gehad om te erken dat Dawid sodoende geslagtelike gemeenskap met die vroue van sy oorlede skoonvader sou gehad het. En dit nie so seer cmdat Dawid vir hulle 'n ideale figuur was nie, as wel omdat volgens ons teks dit die Here self is wat die vroue van Saul aan Dawid in sy skoot gegee sou het. Wel is waar word in die lys van verwantskapsgrade wat $n$ huwelik ongeoorloof maak (Lev. 18:7-18; Lev. 20:11-17; Deut. $23: 1=22: 30$ in die vertalings: $27: 20-23$ ) nie die geval vermeld dat iemand die vroue van sy oorlede skoonvader sou trou, maar blykbaar

1) Gesiteer na die Engelse uitgawe, Biblical Commentary on the Books of Samuel, 1868. 
het Keil en Delitzsch 'n ander beswaar gehad. Hul neem aan, op grond van 1 Sam. 14:50, dat Saul net een vrou gehad het, en as dit so is, dan was daardie vrou, Ahinoam, die dogter van Ahimaäs, die moeder van Dawid se vrou Migal. Die wet verbied uitdruklik (Lev. $18: 17)$ dat 'n man tegelyk met ' $n$ vrou en haar dogter getruud is.

Egter is dit ' $n$ al te strikte vorm van uitlegkunde, om aan te neem dat Saul, omdat 1 Sam. 14:50 slegs een vrou noem, geen ander vroue sou gehad het nie. Ook al moet ons die hof van Séul ons nie al te groots en vorstelik voorstel nie, daar is geen rede om te veronderstel dat die koning hom sou vergenoeg het met die ene Ahinoam en die ene byvrou, Rispa (II Sam. 3:7; 21:8-11). Die woorde „en die vroue van jou heer in jou skoot" is te pertinent om op grond van 'n argumentum e silentio opsy geskuif te word. Ons hoef daarom nog nie te veronderstel dat Dawid werklik vleeslike gemeenskap met die voormalige vroue van Saul gehad het nie; ons sal nog sien dat die harem wat oorgeneem is, seer wel op "non-aktief" gestel kon word; maar dit neem nie weg dat regtens die vroue van Saul volgens ons teks die vroue van Dawid geword het. Juis die uitdrukking ,in jou skoot" suggereer die wettige egverbintenis, vgl. Deut. 13:7; 28:54,56; Sirag 9:1; ook in Gen. 16:5 is die uitspraak "Ek het self my slawin in jou skoot gegee" die aanduiding van 'n wettige egverbintenis, hoe ons twintigste-eeuers ook al mag dink oor die huwelik tussen Abram en Hagar. Juis die vervolg van die geskiedenis toon ons duidelik, dat hierdie huwelik as wettig beskou is en ook regsgevolge gehad het, vgl. codex Hammurabi $\S 144,146,147$, 170,171 .

Maar daar is 'n ander kant aan hierdie uitspraak, wat tot nou toe nie deur die kommentatore opgemerk is. As die harem van 'n oorlede koning deur sy opvolger oorgeneem is, dan sou ons verwag dat die vroue en byvroue van Saul die eiendom van sy regstreekse opvolger, namelik Isboset, sou geword het. En inderdaad tref ons altans die byvrou Rispa aan die hof van Isboset aan (II Sam. 3:6-8). Die moontlikheid bestaan dat dit ook is wat Natan bedoel: nadat hy in die voorgaande vers die naam van Saul genoem het, spreek hy verder oor ,,jou heer" waaronder mens desnoods ook Isboset kon verstaan. Maar wat ons teks ook bedoel mag het, dis seker dat die harem van Saul oorgeneem is deur sy seun Isboset en vervolgens deur Dawid. Die oorname van die harem was een van die amptelike handelinge waardeur die nuwe koning homself in die besit van sy regte stel.

Netnou het ons gespreek van die verblyf van Rispa aan die hof van Isboset. In hierdie verband hoor ons, dat Abner met haar 'n verhouding aangeknoop het, waarvan die wetlike implikasies nie heeltemal duidelik is nie. Die Hebreeuse teks spreek net daarvan, dat 
Abner ,ingegaan het tot", vleeslike gemeenskap gehad het met die voormalige byvrou van Saul; die Septuaginta in die Lucianus-recensie lees egter in vers 7 : ,Saul het 'n bywyf gehad, wie se naam was Rispa die dogter van Aja, e n hy het ha ar geneem." Die gespasieerde woorde, wat in die Hebreeuse teks nie voorkom nie, is die gewone aanduiding van ' $n$ wettige huwelik, vgl. I Sam. $25: 43$.

As die Griekse teks hier korrek is, dan het Abner Rispa getrou. Die dryfveer daartoe sal wel nie in haar skoonheid gelê het nie, maar in die politieke betekenis wat hierdie verbinding kon hê. Die leërhoof, die werklike krag van die Noord-Israelietiese ryk, wou daarmee vir sy landgenote demonstreer, dat hy besig was om die harem van die oorlede koning Saul oor te neem, met ander woorde dat hy, na die ewentuele eliminasie van die swak Isboset, voornemens was om die koningsheerskappy aan sig te trek. As volle neef (I Sam. 14:50, 51, vgl. 9:1, 2) van Saul was hy seker geen onmoontlike kandidaat vir die koningskap nie.

Uit die feit dat Isboset, wat origens sy leërhoof maar laat werskaf het, hom oor hierdie stap ter verantwoording roep, mag ons seker wel opmaak, dat dit na die mening van die koning hoogs gewigtige implikasies gehad het. In sy antwoord, waarin Abner die hele saak as 'n "kwessie oor 'n vrou"2) voorstel, trag hy opsetlik om die betekenis van sy daad te verkleineer. Maar die skrywer van hierdie bybelgedeelte het wel geweet, dat hier meer in gesteek het as Abner op daardie oomblik sou wil toegee: die hele episode word ingelei deur die woorde: "Abner was besig om homself te versterk in die huis van Saul," wat die beste so uitgelê kan word, dat Abner besig was om homself 'n sterk posisie in die huis van Saul te verskaf, vgl. II Kron. $1: 1$; e.e. $\left.{ }^{3}\right)$

Tewens maak ons hieruit op, dat Isboset self geen gebruik gemaak het van die regte, wat hy ten aansien van die harem van sy oorlede vader gehad het nie. Dit kan wees dat hy die besware gèvoel het, wat ons ook in Lev. 18:8 geformuleer vind, vgl. ook duisend jaar later nog I Kor. 5:1. Altans ons merk op dat hy Abner nie verwyt dat hy hom aan een van sy (Isboset se) vroue vergryp het nie. Egter blyk wel uit hierdie geskiedenis, dat die vroue van die voorganger onder die outoriteit van die opvolger geplaas is.

2) Skrap met die Afrikaanse vertaling die lidwoord voor vrou in II Sam. $3: 8$; die woord cawōn het hier seker nie sy volle gewig as uitgedruk in die vertaling "oortreding" nie. Gesenus-Buhl s.v. vertaal ",eine Lappalie."

3) KeIL en DeLITZsCh t.a.p. vertaal: ..And Abner showed himself strong for the house of Saul". Die verbinding van hitchazzē $g$ met die preposisie be kom in die O.T. net hier voor. Die teks Sir. 3: 12, waar ons dieselfde konstruksie vind, laat altwee vertalings toe: , My seun. beywer $u$ vir die eer van u vader en moenie hom verlaat nie al die dae van jou lewe" of: „My seun soek jou krag in die eer van jou vader", ens. 
Die mees bekende geval van oorname van 'n harem is natuurlik die optrede van Absalom, toe hy tydens sy opstand teen sy vader Dawid Jerusalem beset het (II Sam. 16:21,22). Tien bywywe van sy vader was agtergelaat, soos II Sam. 15:16 opmerk, ,om die huis op te pas" - 'n nie baie oortuigende rede! Hoe dit ook mag wees, die vroue was daar en as ' $n$ demonstrasie dat hy nou werklik koning is, en dat sy voorganger, sy vader, in sy oë 'n dooie man is, laat Absalom 'n tent op die dak opslaan - vermoedelik, al word 'n ander woord gebruik, die „chuppa”, die bruilofstent, waarvan die nakomeling nog vandag by die huweliksluiting in die sinagoge gebruik word. In daardie tent is die vroue gebring, en Absalom het demonstratief vir die oë van die bevolking van Jerusalem die tent as bruidegom binnegegaan.

Die meeste kommentatore wat hulle met hierdie afstootlike geskiedenis besig gehou het, veronderstel dat die binnegaan van Absalom tot die vroue net simbolies bedoel is en dat geen werklike gemeenskap plaas gevind het nie. Die woorde waarin die profeet Natan hierdie gebeurtenis voorspel het, dui egter eerder op 'n reële byslaap:" . . sodat hy by jou vroue sal lê voor die oog van hierdie son" (II Sam. 12:11). Ons kan hierdie vraag onbeantwoord laat; vir ons is die hoofsaak die motief, wat Absalom en veral sy raadgewer tot hierdie plan gedryf het. Die Skrif druk hom hier vaag uit: „Dan sal die hele Israel hoor dat u u gehaat gemaak het by u vader, en die hande van almal wat by u is, sal versterk word."

Ons kan dit so verstaan, dat Agitofel bedoel het, dat Absalom deur gemeenskap te hê met vroue, wat in 'n wettige verhouding tot sy vader gestaan het, sy vader 'n belediging toevoeg, wat nie meer goedgemaak kan word nie. Almal in Israel sal weet, dat die breuk tussen vader en seun volkome geword het; dan hoef niemand, wat in ondersteuner van Absalom wil word, te vrees dat die seun hom straks weer met sy vader sal versoen en sy eie aanhangers daaraan sal opoffer nie.

Daarteen kan egter opgemerk word, dat dit tog wel merkwaardig is dat Agitofel nou juis hierdie middel kies om die breuk onherstelbaar te maak. Onwillekeurig soek mens na 'n dieper rede, wat die keus van hierdie middel begrypliker maak. Daardie rede kan gevind word in die feit, dat die corname van die harem een van die seremonies is wat by die troonsbestyging behoort. In hierdie verband is dit opmerklik, dat Absalom van die begin van die opstand hom as koning gedra en so laat betitel (II Sam. 15:10; $16: 16$ ). Selfs Dawid praat eenkeer oor hom as ,die koning" (II Sam. 15:19). Husai spreek oor Absalom as die man wat die twee voorwaardes vir die koningskap vervul het: $\mathrm{Hy}$ is deur die HERE verkies en deur die wettige verteenwoordigers van Israel erken (II Samr. 16:18). In die lyn van die optrede van Absalom as nuwe koning pas die oorname van die harem volkome. Dit was 
die mees pertinente daad waaruit die volk kon opmerk dat Absalom vasberade was om alle konsekwensies uit sy aanspraak op die koningskap te trek.

'n Geval wat baie lyk op die van Abner en Rispa vind ons in I Kon. $2: 13-25$. Adonia vra deur middel van die koning se moeder, Batseba, verlof van die koning Salomo om te mag trou met Abisag. Daaruit merk ons in die eerste plek, dat Abisag, wat tot die harem van die oorledene koning Dawid behoort het (I Kon. 1:2, ,en in u skoot lê"). al het die koning ook geen gemeenskap met haar gehad nie (I Kon. 1:4), met al die ander vroue en bywywe na Dawid se dood onder die outoriteit van sy opvolger Salomo gekom het. Dit is die koning wat ewentueel Abisag ten huwelik sal uitgee.

Uit die reaksie van Salomo op hierdie versoek: sy verontwaardiging en sy besluit, onmiddellik uitgevoer, om Adonia dood te maak, blyk duidelik dat hy ten volle bewus is van die implikasies van hierdie skynbaar eenvoudige saak. Anders as sy moeder Batseba, wat volgens die Bybelse berig nie besef het watter gevare hier dreig nie, verstaan Salomo onmiddellik, dat die huwelik van Adonia met Abisag aan hierdie prins in die oë van die volk n koninklike outoriteit sal skenk. Ons kan ook wel aanneem dat Salomo se vermoede, dat Adonia hierdie stap uit eersug onderneem het, volkome juis was. Anders as Vondel in sy treurspel Adonias neem ons nie aan dat ook die liefde hierby $n$ rol gespeel het nie.

Uit dit alles is dit wel duidelik, dat na die troonsbestyging van die nuwe vors hy die regmatige besitter van die harem van sy voorganger geword het. Ons het reeds aangedui, dat ons daaraan twyfel of daardie oorname van die vroue van die voorganger ook altyd tot reële huweliksgemeenskap gelei het. Die vroue was regtens die besit van die nuwe vors; maar daar was geen verpligting om die besitsreg uit te oefen nie. In ieder geval was daar die uitsondering van die eie moeder, wat soos bekend in Juda onder die titel van gebîra $(h)$, ,die machtige" aansienlike invloed op die gang van sake aan die hof en in die staat uitgeoefen het. Wel is waar staan sy ook onder die outoriteit van die koning, soos blyk uit I Kon. 15:13, maar van 'n, al was dit ook maar formele, huweliksverhouding is geen sprake nie. Daarteen was die tradisionele afkeer van incest te sterk.

Wat het met die ander vroue gebeur? Vermoedelik was hul lot ongeveer die van die onteerde tien bywywe van Dawid: hulle is in 'n "bewaakte huis" gesit; miskien moet ons eintlik vertaal: „in "n huis waar hulle bewaak is". In ieder geval was hulle nie vry om te gaan waar hulle wou nie; die koste van hul lewensonderhoud is deur die koning gedra, maar hy het sy huweliksregte nie aan hul uitgeoefen 
nie, sodat hulle „weduweeskap tydens die lewe”, namelik van die eggenoot, moes dra (II Sam. $20: 3)^{\dagger}$ ). Op dieselfde manier, sonder natuurlik die omskrywing "weduweeskap tydens die lewe", kan ons onderstel dat ook die vroue van die oorlede vors behandel is in die geval dat die opvolger sy seun was en teen gemeenskap met hulle beswaar gevoel het op grond van die bestaande huwelikswette (Lev. 18:8).

Die lot van hierdie vroue is dus wel beklagenswaard: die aandag van die koning strek nie verder as bewaking en lewensonderhoud nie en politieke besware maak dit vir die koning onmoontlik om hulle uit te huwelik.

Anders was die toestand, as die opvolger geen eie seun is nie. Dan was daar geen tradisie wat verbied dat die koning die vroue van sy voorganger werklik tot sy eie vroue maak nie. 'n Sinspeling daarop het ons vermoedelik in I Kon. 20:1-7. Die koning van Damaskus, Benhadad, pretendeer die opperheerskappy ook oor Israel en druk dit uit deur die eis: "U silwer en u goud, dit is myne; en u mooiste vroue en kinders, hulle is myne."'s) Daarin lê opgesluit dat die koning van Israel hom as sy opperheer moet erken, en as vasal sy onderworpenheid moet betoon deur die stuur van huldigingsgeskenke en deur die oorgawe van sy harem.

Die koning van Israel bewillig hierin: „Volgens u woord, my heer die koning, ek is uwe met alles wat ek het!" Blykbaar probeer hy deur 'n blote verklaring van onderworpenheid aan die konflik te ontkom, in die oortuiging dat dit met skatting en oorgawe van die harem nog wel $n$ tydjie sal duur - en ondertussen kan redding kom. Heeltemal anders word egter die situasie as Benhadad die koms van amptenare aankondig wat toe sal sien dat die verklaring ook werklik uitgevoer sal word. Die verdere verloop van die geskiedenis het vir ons doel met hierdie opstel geen betekenis nie. Die belang van hierdie passasie is vir ons net dat die oorwinnende vors die harem van sy kapitulerende teenstander opeis en ewentueel oorneem.

in Ander aanwysing in dieselfde rigting het ons in die berig omtrent die skatting wat Hiskia aan Sanherib van Assur betaal het. Die Bybel vermeld hier net silwer en goud (II Kon. 18:14); Sanherib self in sy inskripsie is hieroor baie uitvoeriger en vermeld: „30 talente goud, 800 talente silwer (volgens die teks in Kon. 300), edelstene, antimo nium, grote sierade (?) van... stene, katels van ivoor, rusbanke van

4) Vgl. vir hierdie uitdrukking die storie oor R. Aqiba, bNed. 50a; die Afriksanse vertaling ..lewenslange weduwees" volg i.p.v. die Masoretiese teks die Septuaginta. wat hier nie nodig is nie.

5 Die voorstel, deur R. KITTEL in Kittel $^{3}$ gedoen. om hier te lees: ..en u mooiste vroue en kinders hulle is uwe" berus op geen enkele tekskritiese grond en sou natuurlik in analoë tekswysiging in vers 5 vereis - waar KITTEL egter niks aanteken nie. Dieselfde geld van vers 7 . 
ivoor, olifantsvelle en olifantstande, urkarinnu-hout, alle moontlike dinge, 'n sware skat, en sy dogrers, die haremvroue van sy paleis, sangers en sangeresse. ${ }^{.6}$ ) Hier is 'n duidelike skeiding tussen sake en persone aangegee. Die sake word saamgevat deur die woord ,'n sware skat"; dit kan ons beskou as die skatting, feitlik 'n huldigingsgeskenk. Maar wat volg dui die oorname van die harem of altans 'n deel daarvan aan. In die eerste plek word die dogters genoem; die moet ons waarskynlik netso beoordeel as die seuns in I Kon. 20:3: hulle het by die moeders behoort en het dus deel van die harem uitgemaak. Dat ons in hierdie verband nie van seuns hoor nie, hoef ons nie te verbaas nie; daar is tekens wat daarop wys dat Hiskia eers laat 'n seun gekry het.')

Vervolgens word die ,haremvroue van sy paleis" genoem. Die lesing van die desbetreffende spykerskrifteken is nie heeltemal seker nie. maar of mens nou met Ungnad $^{8}$ ) sekrēti of met Bezold ${ }^{9}$ ) sjegrēti lees, die woord kom in ieder geval van 'n stam wat ,opsluit" beteken. Dit is vroue, wat geen vryheid van beweging het nie, wat bewaak word. Onwillekeurig kom die gedagte op of Hiskia miskien dié gedeelte van die harem opgeoffer het, wat hy van sy vader Agas geërf het en deur hom op non-aktief gestel is. In ieder geval was die hoofvrou van Hiskia daar seker nie by nie; vroue van in dergelike rang word nie met die woord „opgeslotenes van die paleis" aangedui nie. Dit was in ieder geval 'n laere klas van harem-bewoonsters.

As laaste kategorie word die „sangers en sangeresse" genoem. Vermoedelik daal ons nou nog 'n tree verder die sosiale leer af. Hierdie musikante is geen vryes nie, maar slawe wat vir die vermaak en afwisseling in die harem gedien het, vermoedelik nie maar net deur hul kunstalente nie maar ook deur liggaamlike bekoorlikhedes. 'n Dergelike klasse van mense word ook aan die einde van in lang lys vermeld in Esra 2:65 en Neh. $7: 67$. Daar verskyn hul aan die einde van die sosiale antiklimaks, nog na die gewone slawe en slawinne, en word tereg deur verskillende geleerdes as prostituees e.d. beskou. ${ }^{10}$ ) Ook in Pred. 2:8 verskyn dergelik volk onder die algemene benaming van ,,sangers en sangeresse". "

Dit alles laat mens dink aan die sosiale ordening van die harem by die Hetietiese konings gedurende die Hetietiese Nuwe Ryk. Volgens

6) Seskantige prisma (I Rawlinson 37-42, III, 34-39.

7) So reeds Flavius Josefus, Antiquitates X, 3.

8) A. UnGNad, Babylonisch-Assyrisches Keilschriftlesebuch, 1927, p. 82; vgl. E. Dhorme, Les religious de Babylonie et d' Assyrie, 1945, p. 219.

") C. BEzold. Babylonisch-Assyrisches Glossar, 1926, s.v.

11) Vgl. R. Kittel. Geschichte des Volkes Israel, III, 1927-1929. p. 338.

11) So o.a. W. H. Herrzberg, Der Prediger, 1932. Daarteen rig hom nou G. Cr. Aalders. Het boek de Prediker, 1948, op dit vers, maar met gronde wat menig leser nie sal oortuig nie. 
die uiteensetting van KAMPMAN $^{12}$ ) kan die volgende range onderskeí word: (1) Die tawannannasj, wat vergely kan word met die gebirā $(h)$ in Jerusalem, vgl. hierbo; (2) die esjertu-vroue, wat vermoedelik virygebore was, maar wie se kinders net in die geval dat die tawannannasj kinderloos was, 'n kans op die troon gehad het; (3) die naptartu-v.oue, vermoedelik nie vry-gebore nie, wie se kinders in die Hetieteryk geen reg op die troon kon laat geld nie; ( 4 en 5) twee kategorieë van vroue. wat vermoedelik saamgevat word onder die algemene benaming "paleisvroue", en waarvan die een soort vry - weliswaar nie vry* gebore nie - en die ander soort nog altyd horig was.

Wanneer ons dit nou vergelyk met die gegewens uit die inskripsie van Sanherib, kom ons tot die konklusie, dat Hiskia nie die hoogste in rang, die gebir $\bar{a}(h)$, uitgelewer het nie, en vermoedelik ook nie die groep wat daarop volg nie, wat by die Hettiete die esjertu-vroue geheet het, en waaronder ons die volle vroue in onderskeid van die "bywyve" ens. moet verstaan. Die sekrēti, die "opgeslotenes" van die paleis, kan moeilik vergelyk word met die Hetietiese naptartu-vroue, die "sangers en sangeresse" sou dan die vierde en vyfde kategorie van die Hetietiese harem verteenwoordig. Beter kan ons aanneem dat Hiskia ook die ekwivalent van die naptartu nog uit die hande van die Assiriër kon hou en dat met die "haremvroue van die paleis" die vierde, met die "sangeresse" die vyfde kategorie aangedui is. Dit sou dan n nuwe bewys wees dat die onderwerping van Hiskia aan die opperheerskappy van die Assiriese koning maar 'n heel betreklike karakier gedra het.

Dit alles laat ons weer eenkeer besef hoe min ons feitlik van die Jerusalemse hofhouding en daelikse omgewing van die Jerusalemse konings weet. Sodra as mens probeer om 'n bietjie konkreter en meer gedetailleerde beeld van die gang van sake in paleis en tempel te kry, stuit jy aan al kante op ondoordringbare duisternis.

Dieselfde geld in nog sterker mate van die hofhouding van die Noord-Israelitiese vorstehuise, in die besonder van die hof te Samaria. Dit is die mening an die skrywer van hierdie opstel dat Ps. 45 ons na die ivoorpaleis van die dinastie van Omri bring. Ten onregte word deur byna alle psalmkommentatore aangeneem dat hierdie psalm 'n bruilofslied is. ${ }^{13}$ ) In werklikheid is dit 'n troonsbestygingslied, soos die skrywer binnekort hoop om aan te toon in in afsonderlike studie oor

12) A. A. Kampman,Capita selecta uit de Hethietische beschavingsgeschiedenis; I. Tawannannas, de titel der Hethietische koningin, Jaarbericht Ex Oriente Lux nr. 7, 1940 , p. $432-442$.

13) So ook in die Afrikaanse vertaling, waar die opskrif lui: „Bruilofslied vir die Messias"; en in die "Nieuue Vertaling op last van het Nederlandsch Bijbelgenootschap", 1943. waar dit heet ".Een lied voor de bruiloft des konings". 
hierdie psalm, wat elders sal verskyn. In die verband met ons ondersoek na die oorname van die harem het hierdie lied egter besondere betekenis, omdat dit die gang van die koning in die harem as onderdeel van die kroningsritueel skilder.

Die psalm is buitegewoon reëlmatig in strofes van drie reëls, elk van vier heffings, opgebou. Die sewende tersine skilder die intog van die vors in die paleis, waar die vroue hom vag:

(:9b) Uit die ivoorpaleis verheug u snarespel;

(10) dogters van konings stel hul op om u te begroet, die sjēgal aan $u$ regterhand in goud van Ofîr. ${ }^{14}$ )

Die agste tersine is 'n aanspraak, nie spesiaal tot die sjëgal nie. maar tot elke dogter wat haar in die harem bevind:

(11) Hoor, o dogter en neig u oor, vergeet u geslag en die huis van u vader!

(12a) En die koning sal u skoonheid begeer, want hy is u heer.

Van die negende tersine (: $12 b$ e.v.) af handel die gedig nie meer oor die harem nie, maar oor die geskenke wat by wyse van huldiging deur die omwonende volke gebring word.

Die opbou van die psalm as $n$ geheel is as volg:

1ste tersine: die aanhef

2de $\quad$ d : die verskyning van die jonge koning

3de " : swaardomgording

4 de $\quad$ : crakel wat oorwinning aankondig

$5 \mathrm{de} \quad, \quad$ : intronisasie en septerreiking

6de ." : salwing

7 de $\quad$ : : ingang in die harem

8ste . : toespraak tot die harem

9 de ". huldigingsgeskenke

lode . : huldigingsgeskenke

$11 \mathrm{de} \quad$ " : die nakomelingskap

12de ". : afsluiting.

Uit hierdie opgawe blyk 'n paar dinge duidelik. In die eerste plek dat die tersines twee twee by mekaar geneem kan word. Die ingang in en die toespraak tot die harem vorm sodoende ook 'n harmoniese geheel. Tewens is duidelik, watter plaas die oorname van die harem in die geheel van die kroningsritueel ingeneem het: dit kan eers gebeur as die vernaamste religieuse handelinge verrig is: eers moet die rykswaard oorhandig word, die Godspraak moet verkondig word, die koning moet sy troon bestyg, sy septer in die hand vat en sy hoof laat salf. Maar die oorname van die harem gaan vooraf

14) Pleks van bejiqqerōtèkẫ lees ons (met BuHL in Kittel ${ }^{3}$ ) liqqā ekā; verder niç̧̧ebû i.p.v. niç̧̧ebã $(h)$.

T.S. -3 
aan die huldiging deur die buitelandse en binnelandse vasalle: hulle kry die laaste plaas in die geheel, want wat die koning doen kragtens die Godspraak en uit eie magsvolkomenheid is belangriker as wat die onderdane en buiteiandse relasies doen.

Daar kan ook geen twyfel wees of ons kom in hierdie psalm met heelwat deftiger lede van die harem in aanraking as wat in die inskripsie van Sanherib in verband met Hiskia opgesom word. Die eerste word 'n aantal .,.dogters van konings" genoem: ons moet hier dink aan dogters van die vasalle, konings van rykies soos Moab en Elam, wat in hierdie tyd aan die koning van Samaria skatpligtig was. Maar in besondere ereplek kom blykbaar tot aan die sjêgal. Met hierdie woord weet ons eintlik geen weg nie. Behalwe hier kom dit ook voor in Neh. 2:6, waar dit klaarblyklik in vrou van besonder hoë rang in die harem aandui; by die Persiese hof het dus iets dergeliks bestaan as aan die hof van Samaria. Die verleiding is groot om aan te neem dat met hierdie woord dieselfde posisie aangedui word as dis van die gebira $(h)$ in Jerusalem en van die tawannannasj by die Hetiete. Dog in Daniël 5:2, 3 en 23 kom die woord in die meervoud voor, terwyl die genoemde funksionarisse altyd in die enkelvoud optree. $\left.{ }^{15}\right)$ Dit is juis die eienaardigheid van die posisie van gebirā $(h)$ en tawannannasj dat daar maar net een kan wees, sodat dit selfs uit die Hetietiese geskiedenis duidelik word dat as die koning, die gemaal van die tawannannasj, doodgaan, sy opvolger genoeë moet neem met die feit dat daar reeds 'n tawannannasj is, en nie een van sy vroue tot daardie rang kan verhef nie. ${ }^{16}$ )

Die etimologie van die w'oord sjēgal lê in die duisternis. Daar bestaan 'n werkwoord van die selfde stam, wat op cl die ple'kke waar dit voorkom (Deut. 28:30; Jes. 13:16; Jer. 3:2; Sag. 14:2) vervang is deur n qerē wat die analoë vorm van die werkwoord sjākab substitueer. Blykbaar het die woord in die ore van die latere geslagte buitengewoon obskeen geklink. Op al die genoemde plekke pas die betekenis "onteer" baie goed. Maar dis onmoontlik om van die betekenis van die werkwoord te kom tot 'n nadere bepaling van die naamwoord: want die sēgal is nie 'n vrou wat buite-egtelike gemeenskap het nie, maar inteendeel een van die vernaamste figure uit die koningsharem. Juis uit die onderskeid wat Daniël 5 maak tussen die sjēgal en die lechēna( $h$ ), die koningsvrou en die bywyf, is dit duidelik dat altans volgens die begrippe van daardie tyd die posisie van sjēgal as heeltemaal eervol beskou is.

Opmerklik is, dat die woord. hoewel dit kennelik 'n vroulike

$\left.{ }^{15}\right)$ Dit lyk of die analoë posisie in Daniël 5:10 eenvoudig met .,koningin" (malketa) aangedui is: sy behoort blykbaar tot die vorige generase. soos dikwels by die tawannannasj en gebirã $(h)$ die geval was.

i6) Sien A. A. KampMax t.a.p. p. 435. 
individu aanwys, tog nie die gewone vroulike vorm het nie. Dit is miskien 'n aanwysing, dat die woord van huis uit nie tot die semitiese taalskat behoort nie, maar oorgeneem is uit een van die "Asianiese" tale wat as derde groep tussen die Semietiese en Indogermaanse tale bestaan het. Die moontlikheid bestaan dat dit by wyse van volksetimologie aangepas is aan die werkwoord sjāgal met sy obskene betekenis. Dan sou ons in daardie volksetimologie miskien nog in spoor hê van die kritiek, waarmee die gewone volk en spraakmakende gemeente na die weelderige hof met sy harem-hiërargie gesien het.

Ons sien in ieder geval dat die sjēgal te Samaria n hoëre posisie gehad het as die ,.dogters van konings." Miskien was sy tog die gebirā $(h)$ en het die titel later, in die dae waarin die boek Daniël geskrywe is, sy eksklusiewe betekenis verloor. Die moontlikheid mag trouens nie uitgesluit word nie, dat die woord nieteenstaande sy eienaardige vorm tog van Semitiese herkoms is en werklik etimologies met die werkwoord van "onteer," ,beslaap" saamhang. Die tawannannasj by die Hetiete het spesiale religieuse pligte gehad. vermoedelik veral in verband met die diens van die sonne-godin. ${ }^{17}$ ) Van PuduChepasj, die tawannannasj en gemalin van Chattusjillisj III (1290-1265), weet ons dat sy voor haar huwelik priesteres van Isjtar was. Die vermoede is nie te gewaag nie, dat die Hetietiese tempels dieselfde eienaardigheid had, wat Herodotus van die Babiloniese vertel, namelik dat daar in die tempel altyd een vrou aanwesig is om die godheid by sy besoek aan die tempel as bedgenoot te dien. ${ }^{15}$ ) Dit word des te meer waarskynlik deurdat Herodotus self daaraan toevoeg dat iets dergeliks ook gebruiklik was in die stad Pataroi in Lycië. Sou dit moontlik wees dat die sjēgal oorspronklik haar naam ontleen aan die feit dat sy beskou is as die byslaap van die godheid (vgl. die misjina-woord sjiglōn, vrou wat as byslaap diens doen)? Dit sou dan ook verklaar, waarom die kinders van die tawannannasj die eerste reg op die troonopvolging besit: hulle het gegeld as kinders van die godheid. Die koning is die seun van die godheid by die gemalin van sy voorganger. Hierdie gedagte is algemeen verbreid. Ons ken dit b.v. uit die autobiografiese inskripsies van Hatsjepsut ${ }^{19}$ ); maar ook die Griekse mites soos die van Herakles, wat in die propagandaverhale omtrent die geboorte van Alexander die Grote nog deurwerk.

Wanneer ons nou die reg sou hê om die Samaria-gegewens met die van Jerusalem te kombineer, dan sou ons 'n vrywel volledige Israelietiese parallel van die vyf Hetietiese range in die harem kan konstrueer: die godebruid, die koningsdogters, die vryes, die ,opgeslotenes van die paleis" en die "sangeresse."

17) Sien A. A. Kampman, t.a.p., p. 435.

19) HERODOTUS I, \& 182.

19) K. Sethe, Urkunden der 18. Dynastie, IV. p. 1906, 219-221. 
Ons keer terug tot Ps. 45. Dit bewys in ieder geval, dat die jong koning by sy troonbestyging nie in harem stig nie, maar volledig aantref en in besit neem. Uiteraard word in 'n huldigingslied soos hierdie een net die twee hoogste range genoem, die wat respektiewelik religieuse en politieke betekenis het. Dis trouwens moontlik dat die aanspraak in die agste tersine (vers 11 en 12a) in die besonder tot die vryes, die derde kategorie, gerig is. Die kans dat 'n sjēgal of 'n koningsdagter vir die koning ook om haar uiterlik skoon begerenswaardig is, moet vry gering geag word. Die derde kategorie het egter blykbaar in Israel bestaan uit dogters van die land, wat om hul skoonheid waardig geag is om ' $n$ plek in die harem te kry. Hierteen kan ingebring word dat die vermaning ,vergeet u volk" (so die Afrikaanse en bykans enige ander vertaling) tog eerder aan 'n buitelandse dogter laat dink. Maar ons het vertaal ,vergeet u geslag" en dit op grond van die feit dat die woord 'am baie vaak nie nasie aandui nie, maar 'n veel kleiner sosiale verband, nes partymaal ook ons woord ,"volk"; 'n tiperende voorbeeld daarvan vind ons in II Kon. 4:13, waar "volk" hoogstens in onderdeel van 'n stam kan wees.

Die vermaning sou mens kan betrek op die gevaar, dat die vroue vanuit die harem sou kan probeer om hul eie familie te bevoordeel. Waarskynlik is dit egter nie. 'n Andere moontlikheid is dat die vroue se posisie in werklikheid nie so benydenswaardig was nie en dat party van hulle in die harem met verlange teruggesien het na die dae van die jeug en die kans op ' $n$ normale huwelikslewe in die midde van die geslagsverband. Maar die eenvoudigste is wel om hierdie woorde op te vat as die patriargale teenhanger van die ,matriargale" uitspraak van Gen. 2: 24.

Die laaste voorbeeld van die „oorname van die harem as element in die kroningsritueel," wat ons uit die Israelietiese geskiedenis wil aanhaal, voer ons terug na die oertyd van die Israelietiese volk. Ons dink aan die kort notisie in Gen. 35:22: „En terwyl Israel in dié land woon. het Ruben gegaan en met Bilha, sy vader se bywyf, gemeenskap gehad. En Israel het dit gehoor." Die teks breek

hier op eenmaal af; ook die Masorete het dit gevoel, soos kan blyk uit die feit dat na die woorde ,en Israel het dit gehoor" in die handskrifte 'n ruimte oopgelaat is.

Egter kan ons wel min of meer vermoed, wat daarop gevolg het; want in Gen. 49:3, 4, in die ",seēn van Jakob" word refleksie geneem op hierdie gebeurtenis :

,Ruben, jy is my eersgeborene,

my krag en die eersteling van my sterkte;

die vernaamste in hoogmoed en die vernaamste in mag! 
Opbruising soos van waters-jy sal die vernaamste nie wees nie, want jy het die bed van jou vader beklim;

Toe het jy die leërstede van Bilha ontheilig." ${ }^{20}$ )

Die straf vir die skanddaad was dat aan Ruben sy eersgeboortereg ontneem is, vgl. ook I Kron. 5:1. Wat is egter die verband tussen misdaad en straf in hierdie geval? $\mathrm{Na}$ al wat voorafgegaan het is dit wel duidelik: Ruben het nog tydens die lewe van sy vader wil demonstreer dat hy die toekomstige heerser sal wees en hy het dit gedoen deur geslagtelike gemeenskap te hê met een van die mindere vroue uit Jakob se harem. Die geval het baie ooreenstemming met die van Absalom; in altwee gevalle word dieselfde woord vir bywyf, namelik pilègèsj, gebruik, wat trouwens ook in die geskiedenis van Abner met Rispa voorkom.

Daar is twee verskillende metodes om hierdie geskiedenis op te neem in die totale beeld wat ons van die historie van die Israeliete kan vorm. Die een sien ook hier stamgeskiedenis; daar is inderdaad aanwysings dat die stam Ruben vroeër in die Cisjordaanse gebied gesit het en vandaar verdring is ${ }^{21}$ ): dan beteken die skanddaad met Bilha net dat Ruben 'n tydlank die magtigste van die Lea-stamme was, en geprobeer het om ook sy gesag te laat geld oor die Bilha-stamme Dan en Naftali; daarteen het verset gekom van die res van die Israelgroep onder leiding van die Josef-groepe.

in Ander beskouing gaan uit van die gedagte, dat Jakob nie maar net $n$ stamvader, maar ook 'n stamhoof was, sodat hy feitlik as ' $n$ vors beskou kan word; dan is dit ook heel wel moontlik dat sy seun Ruben analoë planne teen hom gesmee het as later Absalom teen Dawid. Dit bring op eenmaal in staatkundige element in die origens skynbaar pastorale lewe van Jakob: ons het hier dus in parallel van Gen. 14, wat ons onthul dat Abraham ook heelwat meer as 'n privaatman was. In dieselfde rigting, wat Jakob betref, wys trouens ook die sinspeling op Sigem in Gen. $\left.48: 22 .{ }^{2 *}\right)$

Die skrywer van hierdie verhandeling is van mening, dat die tweede alternatief die voorkeur verdien en dat dit 'n kosbaar hulpmiddel is vir die rekonstruksie van die sogenaamde aartsvadertydperk. Maar hoe ons keuse ook uitval, in ieder geval blyk dit dat ons ook hier ' $\mathrm{n}$ voorbeeld het van die gebruik, dat die jonge vors die regmatige erfgenaam van die harem van sy voorganger is, en dat hy sy reg

20) Pleks van die onmoontlike 'âlāi(h) waag die skrywer met Kittel 2 die konjunktuur bilha( $h)$.

21) C Steuernagel, Die Einu'anderung der Israelitischen Stämme in Kanaan, 1901, p. 15 e. vv.

2:1 So F. M. TH. BöHL, De geschiedenis der stad Sichem en de opgravingen aldaar. Mededeelingen der Kon. Akademie van Wetenschappen. deel 62. 1926. 
openlik demonstreer deur tot die vroue, altans deur in hul vertrekke, in te gaan.

Het ons dit eenmaal aangeneem, dan val 'n verrassende lig op die bekende vermelding (I Kon. 11:3), dat Salomo duisend vroue gehad het, namelik sewe honderd „vorstinne" en drie honderd „bywywe" (pilègèsj). 'n Grote deel daarvan was van nie-Israelietiese oorsprong; I Kon. 3:1 gee in opsomming: Moabietiese, Ammonietiese, Edomietiese, Sidoniese, Hetietiese. Die Septuaginta voeg daar nog by ..Aramese," miskien tereg. Dit is opvallend dat dit amper almal name van volke is, wat deur Salomo oorheers is. Mens kan alleen in twyfel geraak oor die Sidoniese; miskien moet ons egter daaronder nie verstaan spesiaal vroue uit die harem van die vors van Sidon, wat sover ons weet nie deur Salomo oorheers is nie, maar van ander, minder belangrike Feniesiese stede. Die moontlikheid bestaan ook, dat Salomo, wat ongetwyfeld ook sy verdrae met ander Feniesiese stede as net Tirus (II Kron. 2) gehad het, die bekragtig het deur huwelike met vorstedogters uit daardie stede, en dat sodoende ook ' $n$ Sidoniese haar intrek in Salomo se harem geneem het. Die „Hetietiese" vorstinne is natuurlik vroue uit die stadstate van die Noordelike Sirie soos Hamat, wat opgekom het uit die desintegrasie van die Hetietiese ryk en waarvan die inskripsies dikwels in die Hetietiese beeldskrif geskryf is. Die "Aramese" vorstinne van die Septuaginta is dan uit die suidelike Sirië, stede soos Soba, afkomstig.

Dit is waarskynlik dat Salomo, in ooreenstemming met die sentraliserende tendense van sy politiek, in heelwat gevalle die vorstehuise van die vasalstate onttroon het, soos I Kon. 11 dit reeds van Dawid verseker. Dit het beteken, dat Salomo as die nuwe vors van hierdie stadstaatjies die regmatige erfgenaam van die harem geword het. En selfs waar die nasionale vorstehuis op die troon gelaat is, het altans 'n deel van die harem die eiendom van die suserein geword, vgl. Sanherib teenoor Hiskia.

in Vraag wat baie min deur die kommentatore gestel is, is die na die moontlikheid, dat in Jerusalem sewe honderd "vorstinne" en driehonderd "bywywe" onder dak gebring word. Ook al hoef ons die ..vorstinne" nie almal as koningsdogters te beskou nie, hulle sal tog wel minstens gelyk gestel moet word aan die esjertu-vroue en die naptartu-vroue van die Hetietiese harem, waaruit volg dat elkeen van hulle 'n aantal slawe en slavinne moes hê. 'n Heel konservatiewe skatting sou wees om aan elk van hulle vyf slawe toe te ken; dit bring die getal van die geheel, saam met die ,bywywe," op 4,500! In 'n stadiie soes Jeruralem, waar ons onder Dawid tog seker nie meer 
as 10,000 mense moet soek nie, sou dit in woningsprobleem van die ergste soort veroorsaak het!

Die oplossing is baie eenvoudig. Soos Jeruralem nooit geannekseer is deur die Israelietiese ryk nie, maar deur Dawid in 'n personele unie met Juda verbind, so het Salomo ook agtereenvolgens in reeks van ander Siro-Palestynse rykies in 'n personele unie met sy eie ryke: Jerusalem, Juda, Israel, Geser, ens. gebring. Daartoe was nodig, dat hy in al daardie stede as koning gehuldig word, en dat hy tydens daardie plegtighede ook telkens die bestaande harem oorneem. Dit beteken egter nie, dat die vroue almal Jerusalem-toe gebring is nie: hulle het gebly waar hulle was, maar is almal gereken as vroue van Salomo. Ons kan selfs aanneem dat hulle name opgeneem is in 'n katalogus, wat in die kanselary van Salomo bygehou is.

So kan ons ook 'n verklaring vind vir die merkwaardige diskrepansie tussen die opgawe van I Kon. 11:3 en die volgende verse uit die Hooglied $(6: 8,9)$ :

,Sestig - hulle is koninginne,

en tagtig - bywywe,

en jong vroue is daar sonder getal.

Een - sy is my duif, my volmaakte,

die enigste van haar moeder,

die uitverkorene van die een wat haar gebaar het.

Die dogters het haar gesien en gelukkig geprys, die koninginne en bywywe, en het haar geroem."

Hierdie lied hou geen rekening met die harems wat in ander dole van Salomo se ryk aanwesig was nie, maar spreek net van die harem wat permanent in Jerusalem vertoef het. Die veronderstelling is nia te stoutmoedig nie, dat dit 'n loflied op die gebira $(h)$ is, wat geprys word bo en deur die ,koninginne," die esjertu-vroue, die bywywe (naptartu-vroue?) en die onvryes, die .,jong vroue," wellig die sekrēti van Hiskia.

Wie was in Salomo se hof die gebîtā $(h)$ ? Gesien die religieuse pligte van die tawannannasj en die sjēgal (vgl. ook vir die godsdienst:ge invloed van die gebirā( $h)$ I Kon. 15:13 en die rol van Atalia) kan dit moeilik aangeneem word dat die dogter van die Egiptiese koning hierdie posisie ingeneem het. Die moeilik verstaanbare opmerking omtrent haar in 1 Kon. 9:24, vgl. II Kron. 8:11, wys daar vermoedelik wel op dat sy geen deel gehad het aan die plegtighede in Salomo se tempel nie. Miskien was sy egter in Geser gebirā $(h)$, want dat die dogter van die Farao in laere rang sou ingeneem het as enige ander. vrou van Salomo kan nouliks aangeneem word. 
Vir gebirā $(h)$ te Jerusalem kom eerder in aanmerking die moeder van Salomo se opvolger, Rehabeam, namelik Naäma die Ammonietiese; dat dit in teencpraak is met die verbod van Deut. 23:3-6 hoef ons in die verband nie as in onoorkomelike beswaar te beskou nie. Mens kry nie die indruk dat in Salomo se dae hierdie soort van bepalings baie krag gehad het nie. Maar die opvolger hoef nie die seun van die gebira(h) te wees nie; dit geld in ieder geval as sy kinderloos is ${ }^{23}$ ); maar ook in ander gevalle kan, deur harem-intriges, onreëlmatighede optree.

$\mathrm{Na}$ die veelvuldige vergelykings wat ons gemaak het tussen die harem in Israel en die in die Hetiete-ryk lê dit voor die hand om te vra of die hele oorsprong van die ,oorname van die harem" as element in die kroningsritueel nie by die Hetiete gesoek moet word nie. Ongelukkig kan ons dit met die gegewens wat tot nou toe beskikbaar is nie bewys nie. Vir sover dit aan die skrywer van hierdie opstel bekend is, word in die Hetietiese tekste geen melding gemaak van die oorname van die harem nie.

Ons kan egter wel op 'n paar ander dinge wys. By sy beskrywing van die regering van die Pseudo-Smerdis vermeld Herodotus dit as n van relf sprekende saak, dat hierdie usurpator as opvolger van Cambyses ook die vroue van Cambyses syne gemaak het (III; 68, 69) en reëlmatig met hulle geslaap het. Hier het ons dus die oorname van die harem op in nie-semietiese terrein. Die feit dat die Persies in Indogermaanse taal is gee egter nog geen reg om hierdie gebruik as sodanig Indogermaans te noem nie.

Daar is nog $n$ ander plek in Herodotus wat in hierdie verband genoem kan word en wat ons digter by die Hetiete bring. In $1: 8-13$ beskrywe die .,vader van die Griekse historiografie" hoe Gyges daarin slaag om Kandaules van die Lydiese troon te stoot. Die verhaal is o.'getwyfeld legendaries opgesier, maar daar is geen rede om aan die ker.? daarvan geen geloof te heg nie. Tot daardie kern reken ons b.v. die vtrmelding dat Gyges partygenote gehad het (\$13) sodat die voor stelling ran Herodotus as sou die troonbestyging van Gyges net $n$ saak van ' $n$ romantiese harem-intrige gewees het, seker onjuis is. Die vraag om 'n orakel voor Gyses as koning erken word, is ook seker 'n historiese trek, en een wat sterk aan die koningserkenning in Israel herinner. Tenslotte is dit ook van belang, dat aan die einde van die novelle Herodotus tot die slotsom kom ( $\$ 12)$ dat Gyges, ,nadat hy Kandaules doodgemaak het tegelyk sy vrou en sy koningskap in hande gekry het." Hiermee is, ontdaan van die romantiese besonderhede, aangedui .dat dit ook in Lydië gebruik was dat die nuwe koning die harem

23) Vgl. die bepalings van Telepinusj, KAMPMAN, t.a.p., p. 435 en 441. 
van sy voorganger oorgeneem het; die enkelvoud "vrou" is waarskynlik te danke aan die behoefte om die geskiedenis te romantiseer. So kan ons dus tot die konklusie kom dat ook vir hierdie gebruik, soos van ander in verband met die koningskap, die agtergrond in Klein Asië, by die Hetiete gesoek moet word. Die verdere ondersoek van die skatte, wat die bodem van Asiaties Turkye nog verborge hou, is daarom van die uiterste belang ook vir die beter verstaan van die Bybelse geskiedenis. Die goeie organisasie van die Turkse oudheidkundige diens, gekombineer met die onsekere politieke verhoudings in die Arabiese lande, sou wellig kan veroorsaak dat in die komende jare die argeoloë nog meer dan tot nou hul aandag op die Klein-Asiatiese vindplekke gaan konsentreer. Ook vir die Ou Testamentiese wetenskappe kan ons dan belangrike gegewens verwag. Dit sou daarom reeds nou van belang wees as ook in Suid-Afrika, besonderlik aan die Universiteit van Pretoria, meer aandag aan die Hetitologie geskenk sou word as wat tot nou toe die geval is.

Pretoria, 27 Augustus 1948.

A. VAN SELMS. 